\title{
The photosynthesis inhibitor metamitron is a highly effective thinner for 'Golden Delicious' apple in a warm climate
}

\author{
Raphael A. Stern ${ }^{\star}$ \\ MIGAL - Galilee Research Institute, P.O. Box 831, Kiryat Shmona 11016, Israel \\ Department of Biotechnology, Faculty of Life Sciences, Tel-Hai College, Upper Galilee 12210, Israel
}

Received 13 July 2014 - Accepted 21 January 2015

\begin{abstract}
Introduction. Small fruit size is a limiting factor in marketing apple (Malus $\times$ domestica). Several techniques have been used to improve fruit size, among them blossom and fruit thinning with plant growth regulators such as auxins and cytokinins to reduce crop load. Materials and methods. In the present study, carried out in 3 consecutive years (2012-2014), we evaluated the photosynthesis inhibitor metamitron (MM) as a thinner for 'Golden Delicious' apple. Results. MM applied once at $180-225 \mathrm{~g} \mathrm{ha}^{-1}\left(150-190 \mathrm{mg} \mathrm{L}^{-1}\right.$ in the form of $0.1 \%-0.125 \%$ Brevis ${ }^{\mathbb{}}$ at $1200 \mathrm{~L} \mathrm{ha}^{-1}$ ) at the 6-mm fruit-diameter stage increased dark-adapted chlorophyll fluorescence, measured as a reduction in $\mathrm{Fv} / \mathrm{Fm}$ values and resulted in significant fruit thinning. Consequently, the average time spent on hand thinning was reduced from 20-30 days ha ${ }^{-1}$ to $2-5$ days $\mathrm{ha}^{-1}$ and there was a considerable and significant shift to larger fruit size. Discussion. The relatively low effective doses of MM compared to those used in Europe and the USA were likely due to the higher night temperatures for 3 weeks postapplication, which increased respiration and caused assimilation deficiencies during that critical period of fruit development. Conclusion. In a warm growing environment the thinner $\mathrm{MM}$ is highly effective on apple, since only one application ( $\mathrm{FB}+7)$ of relatively low dose $\left(190 \mathrm{mg} \mathrm{\textrm {L } ^ { - 1 }} \mathrm{MM}\right.$ as $0.125 \%$ Brevis $^{\circledR}$ ) is enough for optimal fruitlet thinning.
\end{abstract}

Keywords: Israel / apple / Malus domestica / thinning / metamitron / carbohydrate stress / photosynthesis / fruit size

Résumé - Efficacité élevée de l'éclaircissage du pommier 'Golden Delicious' avec l'inhibiteur de photosynthèse métamitron utilisé en climat chaud. Introduction. Un fruit trop petit est un facteur restrictif dans la vente de pommes. Pour contourner ce problème, plusieurs techniques ont été expérimentées, entre autres l'éclaircissage des fleurs et des fruits par des régulateurs de croissance, par exemple auxines ou cytokinines, pour réduire la quantité récoltée. Matériel et méthodes. Dans cette étude étalée sur trois ans (2012-2014), nous avons évalué l'efficacité du métamitron (MM) dans l'opération d'éclaircissage du pommier var. Golden Delicious. Résultats. Une application de MM à une dose de 180-225 $\mathrm{g} \mathrm{ha}^{-1}\left(150-190 \mathrm{mg} \mathrm{L}^{-1}\right.$ sous la forme de $0,1 \%-0,125 \%$ Brevis $^{\circledR}$ à $\left.1200 \mathrm{~L} \mathrm{ha}^{-1}\right)$ au stade de croissance du fruit de $6 \mathrm{~mm}$ de diamètre a augmenté la fluorescence de la chlorophylle adaptée à l'obscurité, mesurée en fonction de la réduction du rapport $\mathrm{Fv} / \mathrm{Fm}$, et a augmenté l'éclaircissage des fruits de façon significative. En conséquence, le temps requis pour effectuer l'éclaircissage de façon manuelle a été réduit de 20-30 jours ha ${ }^{-1}$ à 2-5 jours ha ${ }^{-1}$, et la dimension des fruits a été augmentée de façon significative. Discussion. L'efficacité du MM à faible dose en comparaison aux doses pratiquées en Europe et aux États-Unis est probablement due à la température nocturne élevée pendant les trois semaines consécutives à l'emploi du MM. Cette température a accentué la respiration du fruit et a réduit l'assimilation de glucides durant la période critique du développement du fruit. Conclusion. Sous climat chaud l'éclaircisseur de pommes $\mathrm{MM}$ se montre particulièrement efficace, puisqu'un seul traitement au stade $\mathrm{FB}+7$ à une dose relativement faible $\left(190 \mathrm{mg} \mathrm{L}^{-1} \mathrm{MM}\right.$ à $0,125 \%$ du produit commercial Brevis $\left.{ }^{\circledR}\right)$ est suffisant pour assurer un éclaircissage optimal.

Mots clés : Israël / pommier / Malus domestica / éclaircissage / métamitron / stress carboné / photosynthèse / calibre du fruit

\section{Introduction}

'Golden Delicious' apple trees (Malus $\times$ domestica Borkh.) produce an excessive number of fruitlets. The higher

\footnotetext{
^ Corresponding author: raffi@ migal.org.il
}

production reduces fruit size and induces alternate bearing. To obtain larger fruit every year, fruit thinning has become an essential practice in the commercial production of quality apple fruit [1]. Since hand-thinning is laborious and costly, it is not a general practice in orchard management. Instead, the use of chemicals to thin flowers or fruitlets is 
customary [2-4]. Several compounds have been used for this purpose, among them the synthetic auxins 1-naphthaleneacetic acid (NAA) or naphthaleneacetamide (NAD). These compounds are involved in the formation of abscission layers and cause fruit drop through activation of ethylene, which induces the hydrolytic enzymes polygalacturonase and cellulase [5]; they also increase dark respiration and decrease photosynthesis [6,7]. Another compound used for thinning is the cytokinine 6-benzyladenine (BA), which has been shown to block embryo development by causing severe reductions in carbohydrate levels; this, in turn, reduces polar auxin transport across the fruit pedicel and enhances the abscission zone's sensitivity to ethylene, leading to fruit drop $[8,9]$.

The triazinone herbicide metamitron (MM) has been recently reported to have thinning activity in apple via inhibition of photosynthesis [10,11]. Specifically, it is a photosystem II (PSII) inhibitor that disrupts the photosynthetic apparatus for 7 to $10 \mathrm{~d}$ after application, reducing electron transport rates [12]. The normalized ratio of variable fluorescence to maximum fluorescence $(\mathrm{Fv} / \mathrm{Fmax})$ represents the maximum potential quantum efficiency of PSII, which is $c a .0 .80$ in most plant leaves [13]. Changes in this ratio after treatment were used to study the effect of MM on photosynthesis inhibition. MM exhibited thinning activity when applied to apple fruitlets at the $10-$ to $12-\mathrm{mm}$ diameter stage $([10,11]$ or even later, at $20 \mathrm{~mm}$ [12]. The objective of the present study was to compare the new thinning agent $\mathrm{MM}$ (Brevis ${ }^{\mathbb{B}}$ ) to the commercial auxins NAA and NAD (Agriton ${ }^{\circledR}$ ) and the commercial cytokinin BA $\left(\mathrm{MaxCel}^{\mathbb{R}}\right)$ applied to 'Golden Delicious' apple grown in the warm climate of Israel.

\section{Materials and methods}

\subsection{Experimental orchards and conditions}

Experiments were conducted over three seasons between 2012 and 2014 on mature 'Golden Delicious' apple trees $\times$ MM 106 rootstock in two orchards: (i) at Ortal, located in the Golan Heights, $950 \mathrm{~m}$ above sea level (asl). The trees were $3.0 \mathrm{~m}$ high, at $4.5 \mathrm{~m} \times 2.2 \mathrm{~m}$ spacing $\left(1,010\right.$ trees $\left.\mathrm{ha}^{-1}\right)$; (ii) at Matityahu orchard located in the Upper Galilee, $700 \mathrm{~m}$ asl. The trees were $3.3 \mathrm{~m}$ high with the same spacing as in Ortal.

Both orchards were located in a semiarid region with high temperatures ( $\mathrm{ca} .35^{\circ} \mathrm{C}$ max.) and low humidity ( $\left.<40 \% \mathrm{RH}\right)$ during the summer (May-October). Annual rates of precipitation (November-April) were approx $700 \mathrm{~mm}$ and $900 \mathrm{~mm}$ at Matityahu and Ortal respectively. The soil at both sites was $0.8-1.2 \mathrm{~m}$ deep, and classified as a well-drained protogromosol (68\% clay) on terra rossa soil at Matityahu, or on basaltic rocks at Ortal. The soil $\mathrm{pH}$ was 7.7 at Matityahu and 7.3 at Ortal with a $\mathrm{CaCO}_{3}$ content of approx $7 \%(\mathrm{w} / \mathrm{w})$ at both sites. The irrigation system at both sites consisted of two lateral lines per row, placed $1.0 \mathrm{~m}$ apart, with $1.6 \mathrm{~L} \mathrm{~h}^{-1}$ pressure-compensated in-line drippers (Netafim, Iftach, Israel) spaced $0.5 \mathrm{~m}$ apart.

\subsection{Chemical application}

Three commercial products, containing auxin, cytokinin or MM, were applied: (1) $\operatorname{Agriton}^{\circledR}$, a liquid formulation containing $1.8 \%(\mathrm{v} / \mathrm{v})$ NAD plus $0.68 \%(\mathrm{v} / \mathrm{v})$ NAA, manufactured by Nufarm, France; (2) $\mathrm{MaxCel}^{\mathbb{R}}$, a liquid formulation containing $1.9 \%(\mathrm{v} / \mathrm{v}) 6-\mathrm{BA}$, manufactured by Valent BioScience USA; (3) Brevis ${ }^{\circledR}$, containing 15\% (w/w) MM, manufactured by Makhteshim-Agan, Israel.

Chemicals were applied as a foliar spray at $1.2 \mathrm{~L}$ tree $^{-1}$ using a high-pressure handgun [Experiments (Expt.) 1 and 2] or at 1,200 $\mathrm{L} \mathrm{ha}^{-1}$ using an air-blast 'Spidet' blower sprayer (Expt. 3 and 4, semi-commercial trials). The nonionic surfactant Triton X-100 was only included in the commercial control of the Agriton ${ }^{\circledR}$ treatments at $0.025 \%(\mathrm{v} / \mathrm{v})$. Control trees were not sprayed but hand-thinned in mid-June with $c a$. 20-30 days of work $\mathrm{ha}^{-1}$ in all experiments.

Expt. 1 (2012). In a preliminary experiment, conducted in 2012, three concentrations of Brevis ${ }^{\mathbb{R}}$ (MM) applied at full bloom +7 days $(\mathrm{FB}+7=6$-mm diameter stage; $\mathrm{I}) \mathrm{FB}+14$ (10-mm stage; II) or both (I+II), were examined:

1. $0.06 \%=90 \mathrm{mg} \mathrm{L}^{-1} \mathrm{MM}=110 \mathrm{~g} \mathrm{MM} \mathrm{ha}^{-1}(\mathrm{MM} 110 \mathrm{I}$ or MM 110 II or MM 110 I+II);

2. $0.08 \%=120 \mathrm{mg} \mathrm{L}^{-1} \mathrm{MM}=145 \mathrm{~g} \mathrm{MM} \mathrm{ha}^{-1}(\mathrm{MM} 145 \mathrm{I}$ or MM 145 II or MM 145 I+II);

3. $0.10 \%=150 \mathrm{mg} \mathrm{L}^{-1} \mathrm{MM}=180 \mathrm{~g} \mathrm{MM} \mathrm{ha}^{-1}(\mathrm{MM} 180 \mathrm{I}$ or MM $180 \mathrm{II}$ or MM $180 \mathrm{I}+\mathrm{II})$.

The commercial control was Agriton ${ }^{\circledR} 0.4 \%=73 \mathrm{mg} \mathrm{L}^{-1}$ $\mathrm{NAD}+27 \mathrm{mg} \mathrm{L}^{-1} \mathrm{NAA}$ at $\mathrm{FB}+3$. The control treatment did not receive any chemical treatment.

Expt. 2 (2013). In 2013, the experiment was conducted with a new set of trees in the same orchard as Expt. 1. We increased the MM concentration to $190 \mathrm{mg} \mathrm{L}^{-1}=$ $225 \mathrm{~g} \mathrm{MM} \mathrm{ha}^{-1}\left(0.125 \%\right.$ Brevis $\left.^{\circledR}\right)$ examined only once at $\mathrm{FB}+7$ and compared it to the highest concentration of Expt. 1 $\left(150 \mathrm{mg} \mathrm{L}^{-1} \mathrm{MM}=180 \mathrm{~g} \mathrm{MM} \mathrm{ha}^{-1}=0.1 \%\right.$ Brevis $\left.^{\circledR}\right)$ which was examined once at $\mathrm{FB}+7$ or $\mathrm{FB}+14$ or twice (on both dates). The commercial controls were Agriton ${ }^{\circledR} 0.4 \%$ at $\mathrm{FB}+3$ and $\mathrm{MaxCel}^{\circledR} 0.75 \%=\mathrm{BA}\left(150 \mathrm{mg} \mathrm{L}^{-1}\right)$ at $\mathrm{FB}+7$. Untreated control trees did not receive any chemical treatment. In addition the return bloom of trees from Expt. 1 (2012) was recorded in spring 2013 by measuring the flowering intensity per tree $(0=$ no flowering; $1=$ low, $2=$ medium, and $3=$ high flowering).

Expt. 3 (2013). A semi-commercial experiment was conducted in 2013 at Ortal orchard. One application of the highest concentration of $190 \mathrm{mg} \mathrm{L}^{-1} \mathrm{MM}=225 \mathrm{~g} \mathrm{MM} \mathrm{ha}^{-1}$ $\left(0.125 \%\right.$ Brevis $\left.^{\circledR}\right)$ at $\mathrm{FB}+7$ or two applications of $0.125 \%$ Brevis $^{\circledR}\left(225 \mathrm{~g} \mathrm{MM} \mathrm{ha}^{-1}\right)$ at $\mathrm{FB}+7$ plus $0.08 \%$ Brevis $^{\circledR}$ $\left(145 \mathrm{~g} \mathrm{MM} \mathrm{ha}^{-1}\right)$ at $\mathrm{FB}+14$ were examined in comparison to untreated control trees.

Expt. 4 (2014). In 2014 another semi-commercial experiment was conducted in the same orchard as Expt. 1 and 2. One application of 190,225 or $270 \mathrm{~g} \mathrm{MM} \mathrm{ha}^{-1}(0.1 \%, 0.125 \%$ or $0.15 \%$ Brevis $^{\circledR}$, respectively) at $\mathrm{FB}+7$ was examined in comparison to untreated control trees. Two new measurements were performed:

1. Photosynthesis inhibition: Chlorophyll fluorescence measurements were carried out on five recently fully expanded leaves from four trees per treatment (three concentrations of MM vs. untreated control trees) every other day for 10 days after MM application. Fluorescence was measured 


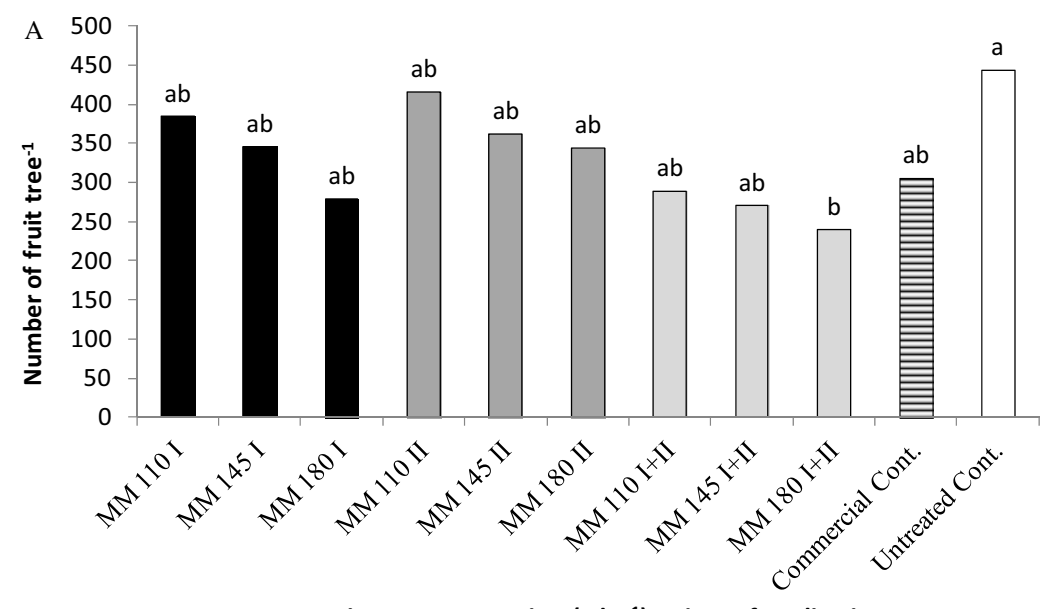

Metamitron concentration $\left(\mathrm{g} \mathrm{ha}^{-1}\right)+$ time of application

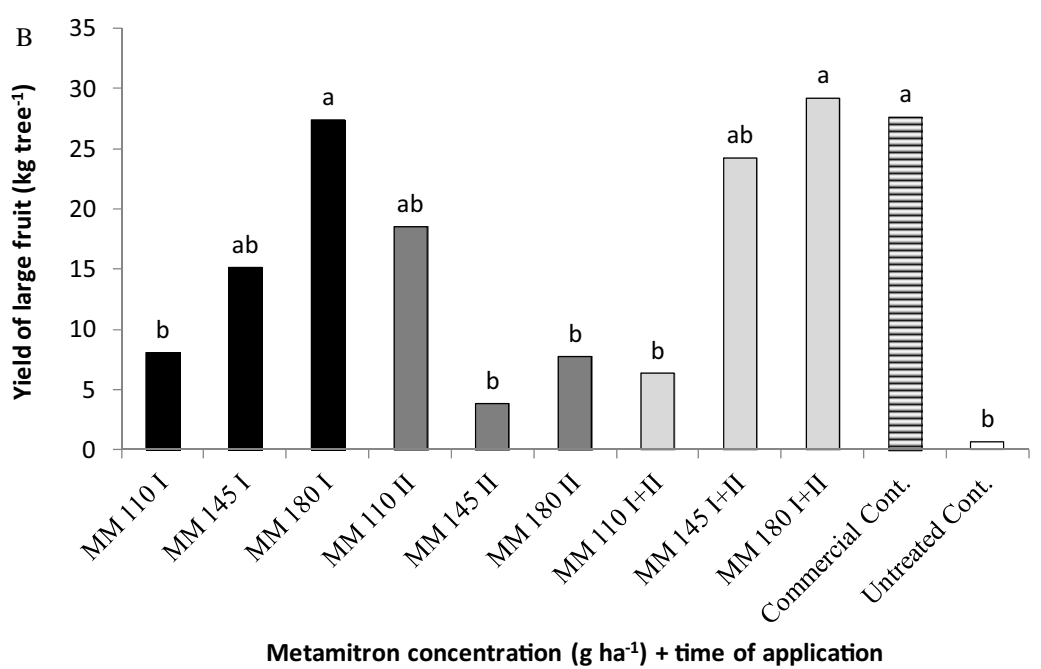

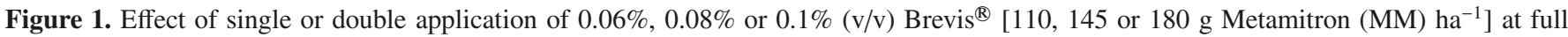
bloom (FB) + 7 days (I), FB + 14 days (II) or both (I+II), or single application of $0.4 \%$ (v/v) Agriton ${ }^{\circledR}\left(73 \mathrm{mg} \mathrm{L}^{-1} \mathrm{NAD}\right.$ plus $\left.27 \mathrm{mg} \mathrm{L}{ }^{-1} \mathrm{NAA}\right)$ at FB + 3 days as a commercial control on the number of fruit per tree (A) and the yield of large fruit per tree (B). Treatments were applied at $1.2 \mathrm{~L}$ tree $e^{-1}$ using a handgun sprayer. Each data point is the mean of six trees per treatment. Different letters denote significant differences between the means according to Duncan's new multiple range test (DMRT) at $P \leqslant 0.05$. (Expt. 1).

in the dark between 5:00 am and 6:00 am, using a portable "Mini-Pam" Photosynthesis Yield Analyzer (Heinz Walz $\mathrm{GmbH}$, Effeltrich, Germany).

2. Fruit-set percentage: At the balloon stage, 500 flowers per treatment $(5$ flowers per cluster $\times 5$ clusters per branch $\times$ five 3 -year-old branches with similar spurs $\times 4$ trees) were labeled at $c a$. $1.5 \mathrm{~m}$ height, always on the south side of the row. The percentage of initial fruit set was determined 3 weeks after treatment (1 May 2014), before June drop.

\subsection{Statistical analysis}

The experiment consisted of a randomized complete block design, with six replicates (blocks) of 1 tree per treatment (Expt. 1 and 2) or four replicates of 10 trees per treatment (Expt. 3). At harvest, the yield from each tree was weighed and all fruit were sorted according to diameter: small $(<65 \mathrm{~mm})$, medium $(65-75 \mathrm{~mm})$ or large $(>75 \mathrm{~mm})$.
Percentage data were subjected to arcsine transformation before analysis to provide a normal distribution. Data were analyzed for statistical significance using a general linear model (GLM) procedure. Duncan's new multiple range test (DMRT) was used to compare treatments when ANOVA showed significant differences among means using JMP software (SAS Institute Inc., Cary, NC, USA).

\section{Results}

\subsection{Preliminary experiments}

In the preliminary experiment (Expt. 1 - 2012), the MM treatments had thinning effects (figure $1 A$ ). However, there was only one treatment that was significantly different from the control. Nevertheless, there was a trend of response to dose and time of application. At both application times (FB+7 and $\mathrm{FB}+14)$ the highest concentration of $180 \mathrm{~g} \mathrm{MM} \mathrm{ha}^{-1}$ reduced 


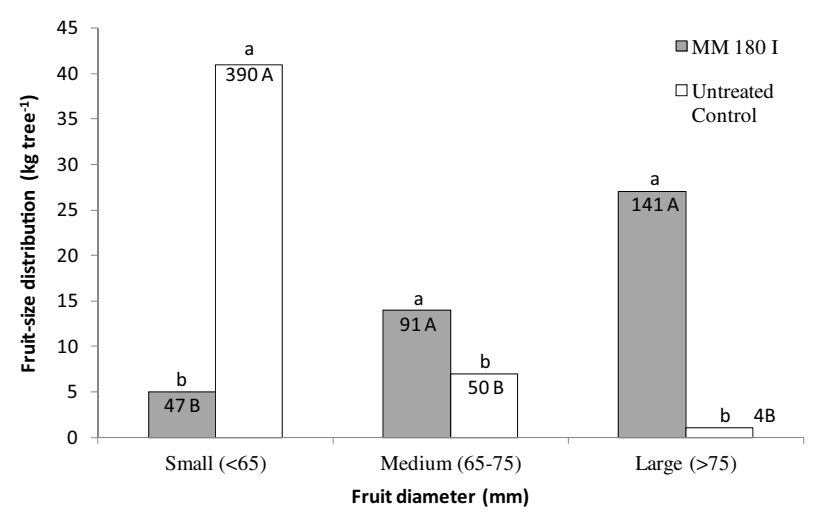

Figure 2. Effect of the optimal Metamitron (MM) treatment from Expt. 1: $180 \mathrm{~g} \mathrm{MM} \mathrm{ha}^{-1}$ as $0.1 \%$ (v/v) Brevis ${ }^{\circledR}$ at full bloom (FB) +7 days on fruit-size distribution. Different lowercase or uppercase letters within each size group denote significant differences between the means of $\mathrm{kg}$ tree $^{-1}$ or fruit no. tree ${ }^{-1}$ (means in the bars), respectively, according to DMRT at $P \leqslant 0.05$.

the fruit number compared to the intermediate and lowest concentrations (145 and $110 \mathrm{~g} \mathrm{MM} \mathrm{ha}^{-1}$ respectively) although not significantly. However, the efficiency of the treatments at the early application $(\mathrm{FB}+7)$ was higher albeit not significantly so, compared to the late application at $\mathrm{FB}+14$ (figure 1A); as a result the yield of large fruit from the early treatments was much higher (figure $1 B$ ). For example: $180 \mathrm{~g} \mathrm{MM} \mathrm{ha}^{-1}$ at $\mathrm{FB}+7$ reduced the number of fruit per tree from 444 in the control trees to 279 and as a result gave a high yield of large fruit: $27 \mathrm{~kg}$ tree ${ }^{-1}$ compared to only $1 \mathrm{~kg}$ tree $\mathrm{e}^{-1}$ in the untreated controls (figure 1B). The same concentration but at $\mathrm{FB}+14$ reduced the fruit number to 345 and the yield of large fruit was only $8 \mathrm{~kg}$ tree $^{-1}$. Two applications at each of these concentrations did not improve the results of only one application at $\mathrm{FB}+7$. The fruit-size distribution after the optimal treatment $\left(180 \mathrm{~g} \mathrm{MM} \mathrm{ha}^{-1}\right.$ at $\left.\mathrm{FB}+7\right)$ vs. untreated control trees shows that this treatment also doubled the yield of the medium fruit size and dramatically reduced the yield of small fruit (figure 2). The commercial control Agriton ${ }^{\circledR}$ (NAD+NAA) gave results similar to those of the optimal MM treatment.

In the second year (Expt. 2 - 2013), we examined the optimal concentration found in Expt. $1\left(180 \mathrm{~g} \mathrm{MM} \mathrm{ha}^{-1}\right)$ given at $\mathrm{FB}+7, \mathrm{FB}+14$ or both. In addition we increased the concentration to $225 \mathrm{~g} \mathrm{MM} \mathrm{ha}^{-1}$ but only at the earlier application of $\mathrm{FB}+7$, which showed better results than $\mathrm{FB}+14$. All MM treatments showed a strong thinning effect which influenced fruitsize distribution, i.e., $\mathrm{ca}$. half the yield of small fruit (approx. 20 vs. $40 \mathrm{~kg} \mathrm{tree}^{-1}$ ) and about 10 -fold that of large fruit with no influence on the yield of medium-size fruit (figure 3). However, $180 \mathrm{~g} \mathrm{MM} \mathrm{ha}^{-1}$ at $\mathrm{FB}+7$ was enough to produce optimal results. The higher concentration of $225 \mathrm{~g} \mathrm{MM} \mathrm{ha}^{-1}$ or two applications of $180 \mathrm{~g} \mathrm{MM} \mathrm{ha}^{-1}$ were not better than only one early application $(\mathrm{FB}+7)$ at the lower dose $\left(180 \mathrm{~g} \mathrm{MM} \mathrm{ha}^{-1}\right)$. As in Expt. 1 the late application at FB+14 was less efficient than the early one. The commercial controls gave good results, especially with Agriton ${ }^{\circledR}$ (NAD+NAA).

The return bloom in spring 2013 on trees from Expt. 1 (2012) showed no negative effects compared to the untreated control trees (figure 4). In fact, it was even slightly, albeit not significantly, higher. The optimal treatment of $180 \mathrm{~g} \mathrm{MM} \mathrm{ha}^{-1}$ at $\mathrm{FB}+7$, which reduced fruit number and improved fruit-size distribution in 2012 (Expt. 1) was again the best treatment: it almost doubled the flowering intensity, while the same concentration but at later application $(\mathrm{FB}+14)$ gave much lower flowering similar to all other treatments at late application.

\subsection{Semi-commercial experiments}

In the semi-commercial experiment with the air-blast sprayer (Expt. 3 - 2013 at Ortal) we expected a high yield. Therefore, we examined the highest concentration from Expt. $2\left(225 \mathrm{~g} \mathrm{MM} \mathrm{ha}^{-1}\right)$ at $\mathrm{FB}+7$ compared to the same treatment plus another application of $145 \mathrm{~g} \mathrm{MM} \mathrm{ha}^{-1}$ at $\mathrm{FB}+14$. Indeed, the yield was high $\left(85 \mathrm{~kg}\right.$ tree $\left.e^{-1}=85 \mathrm{t} \mathrm{ha}^{-1}\right)$ and both treatments reduced fruit number considerably (data not shown). As a result the fruit-size distribution was improved, with a lower yield of small fruit $(<65 \mathrm{~mm})$ and higher yield of medium $(70 \mathrm{~mm})$ and large $(>75 \mathrm{~mm})$ fruit (figure 5$)$. As in Expt. 1 and 2, the second application of MM did not give better results than only one application at the earlier time $(\mathrm{FB}+7)$.

In the third year (Expt. 4 - 2014) we conducted another semi-commercial experiment to examine the higher concentration of $270 \mathrm{~g} \mathrm{MM} \mathrm{ha}^{-1}\left(0.15 \%\right.$ Brevis $\left.^{\circledR}\right)$ at the optimal time of application $(\mathrm{FB}+7)$. All MM treatments reduced the maximum potential quantum efficiency of PSII from 1 to 7 days after treatment, measured as an increase in dark-adapted chlorophyll fluorescence (reduction in $\mathrm{Fv} / \mathrm{Fm}$ values) compared to the untreated control (figure 6). However, the lowest dose of $180 \mathrm{~g} \mathrm{MM} \mathrm{ha}^{-1}\left(0.1 \%\right.$ Brevis $\left.^{\circledR}\right)$ had only a slight effect compared to the moderate dose of $225 \mathrm{~g} \mathrm{MM} \mathrm{ha}^{-1}(0.125 \%$ Brevis $^{\circledR}$ ), which reduced the $\mathrm{Fv} / \mathrm{Fm}$ values dramatically from ca 0.8 in control trees to only $c a$. 0.4. The highest dose of $270 \mathrm{~g} \mathrm{MM} \mathrm{ha}^{-1}\left(0.15 \%\right.$ Brevis $\left.^{\circledR}\right)$ did not differ from the moderate dose.

The initial fruit-set percentages of all MM treatments were lower than the control and showed a considerable dose response. The lowest dose had only a slight effect $(55.4 \%$ vs. $59.4 \%$ in the control trees), while the intermediate and highest doses reduced the fruit-set percentage to $22.6 \%$ and $19.6 \%$ respectively i.e. one-third of the control. The correlation between $\mathrm{Fv} / \mathrm{Fm}$ values as an average of all effected period $(\mathrm{FB}+7$ until $\mathrm{FB}+17)$ and the initial fruit-set percentage was positively and significantly high $\left(R^{2}=0.95 ; P=0.05\right)$.

In control trees 20-30 days ha ${ }^{-1}$ were needed for handthinning at the end of June, compared to $2-5$ days ha ${ }^{-1}$ following the optimal treatment in each year, depending on crop load.

\section{Discussion}

\subsection{Plant metabolism involved}

Small size is one of the limiting factors in marketing apple fruit; therefore, the economic benefits of treatments that 


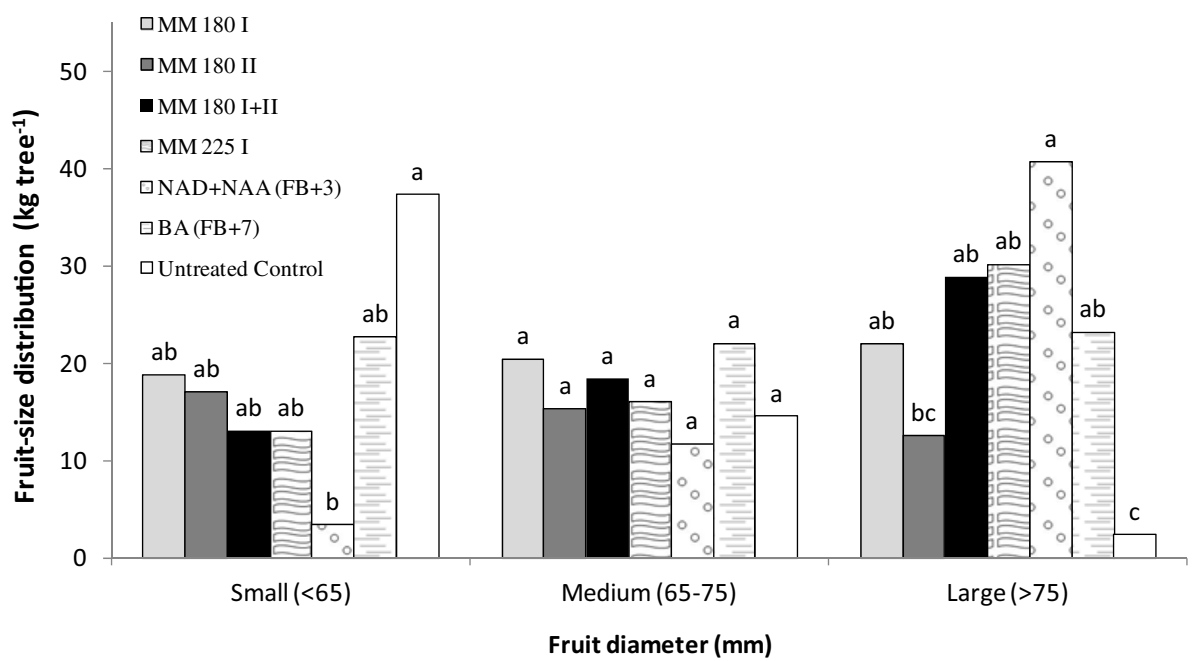

Figure 3. Effect of single or double applications of $0.1 \%$ or $0.125 \%(\mathrm{v} / \mathrm{v})$ Brevis ${ }^{\circledR}\left[180\right.$ or $225 \mathrm{~g}^{\text {Metamitron }}(\mathrm{MM})$ ha $\left.{ }^{-1}\right]$ at full bloom (FB) +7 days (I), FB + 14 days (II) or both (I+II), a single application of $0.4 \%$ (v/v) Agriton ${ }^{\circledR}\left(73 \mathrm{mg} \mathrm{L}^{-1} \mathrm{NAD} \mathrm{plus} 27 \mathrm{mg} \mathrm{L}{ }^{-1} \mathrm{NAA}\right)$ at FB + 3 days, or a single application of $0.75 \%(\mathrm{v} / \mathrm{v}) \mathrm{MaxCel}^{\circledR}\left(150 \mathrm{mg} \mathrm{L}^{-1} \mathrm{BA}\right)$ at $\mathrm{FB}+7$ days on fruit-size distribution (Expt. 2). Each data point is the mean of six trees per treatment. Different letters within each size group denote significant differences between the means according to DMRT at $P \leqslant 0.05$.

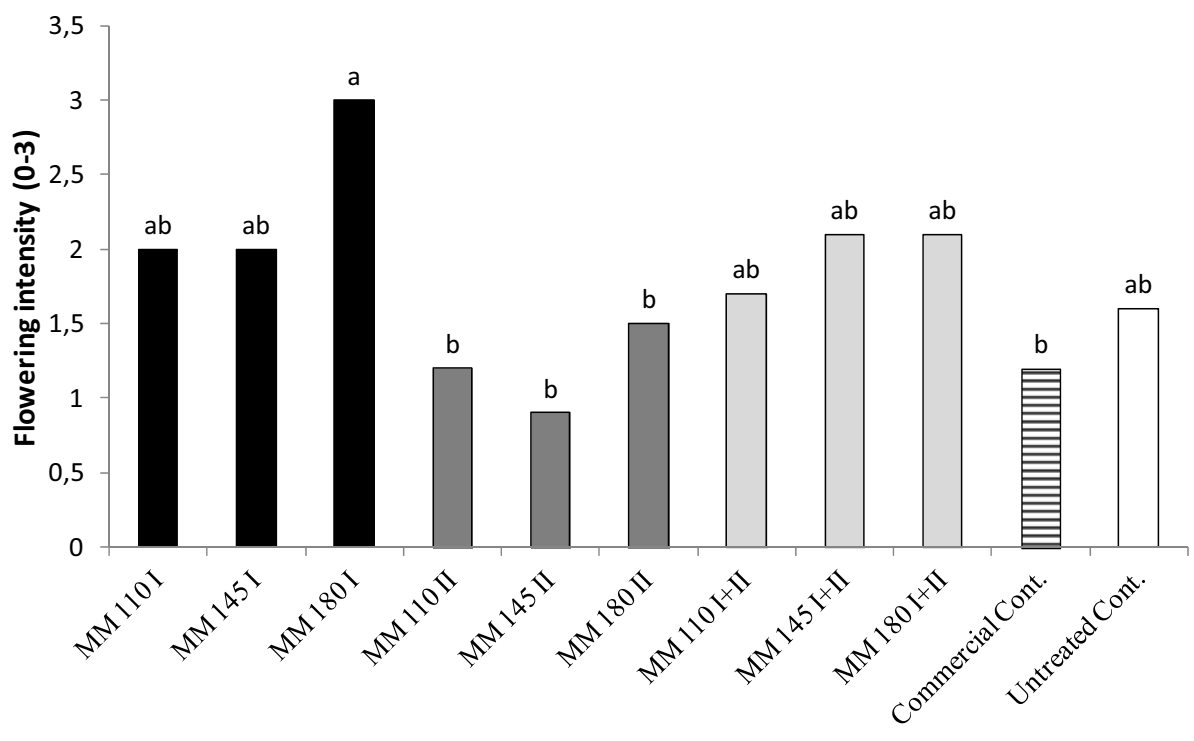

Figure 4. Effect of treatments in 2012 (Expt. 1) on the return bloom in spring 2013. Flowering intensity per tree was recorded as follows: $0=$ no flowering; 1 = low; 2 = medium, and 3 = high flowering. Different letters denote significant differences between the means according to DMRT at $P \leqslant 0.05$.

can improve average fruit size are potentially very high $[1,14]$. Several techniques have been used to improve apple fruit size, among them application of synthetic cytokinins such as CPPU or $\mathrm{BA}$ at $\mathrm{FB}+14$, to stimulate cell division in the fruit $[15,16]$. However, when the number of fruit is too high, the efficiency of these treatments decreases because of the limited supply of assimilates from the leaves. Another approach to increase fruit size is by reducing fruitlet number from the beginning of fruit growth $[2,4,14]$. This can be achieved by limiting the production of carbohydrates in the tree during the 2- to 3-weeks period after bloom, precisely when the demand for assimilates by the fruitlets is highest [17]. This is supported by Botton et al. [8], who showed a carbohydrate deficit in the trees and fruit cortex immediately after treatment with 6-BA, which caused lateral fruit abscission, and by Dash et al. [18], who showed a reduction in early fruit growth of apple and thinning after severe shading which limited carbohydrate production and decreased cell production and expansion.

Recent reports have accumulated from the USA and Europe on the PSII inhibitor MM, whose reduction of photosynthesis reduces fruit set in apples when applied at the 6- to 10-mm diameter fruit stage [10-12]. Indeed, our results from 2014 (Expt. 4) support this. However in all of those reports, the optimal amount of MM was ca. 250-350 $\mathrm{g} \mathrm{ha}^{-1}$ at the 


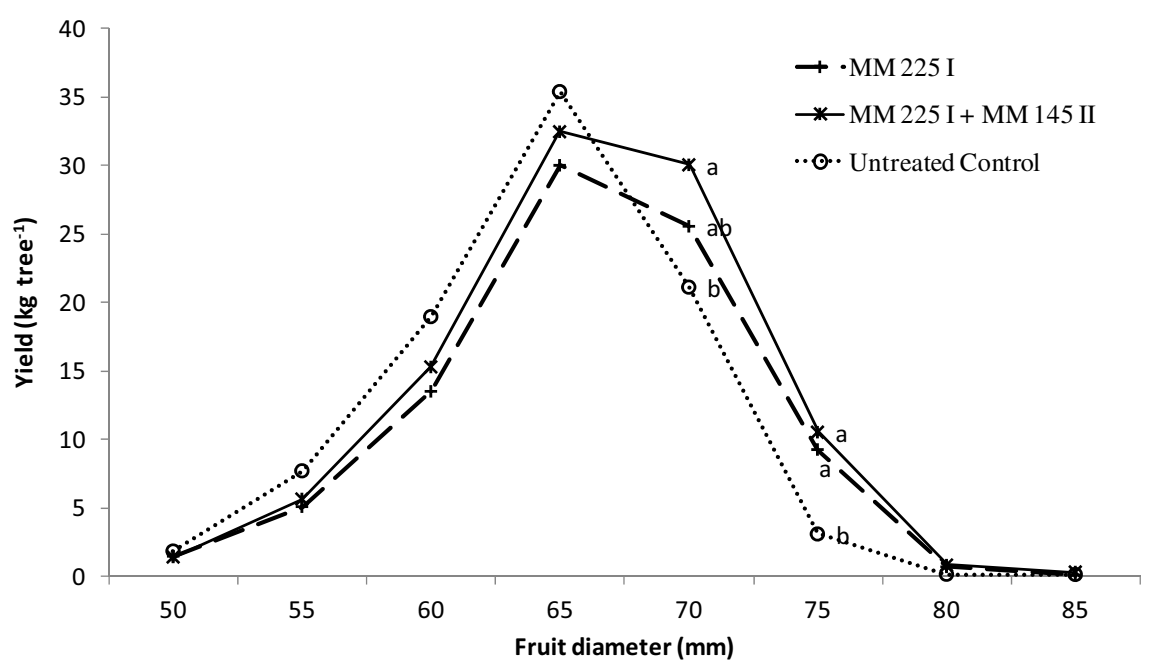

Figure 5. Effect of one application of $0.125 \%(\mathrm{v} / \mathrm{v})$ Brevis ${ }^{\circledR}\left[225 \mathrm{~g}\right.$ Metamitron $\left.(\mathrm{MM}) \mathrm{ha}^{-1}\right]$ at full bloom (FB) $+7 \mathrm{~d}(\mathrm{I})$ or two applications of $0.125 \%(\mathrm{v} / \mathrm{v})$ Brevis $^{\circledR}$ given at FB $+7 \mathrm{~d}(\mathrm{I})$ and $0.08 \%(\mathrm{v} / \mathrm{v})$ Brevis ${ }^{\circledR}\left(145 \mathrm{~g} \mathrm{MM} \mathrm{ha}^{-1}\right)$ at FB $+14 \mathrm{~d}$ (II) on fruit-size distribution (Expt. 3). Each data point is the mean of 40 trees per treatment. Different letters within each size group denote significant differences between the means according to DMRT at $P \leqslant 0.05$.

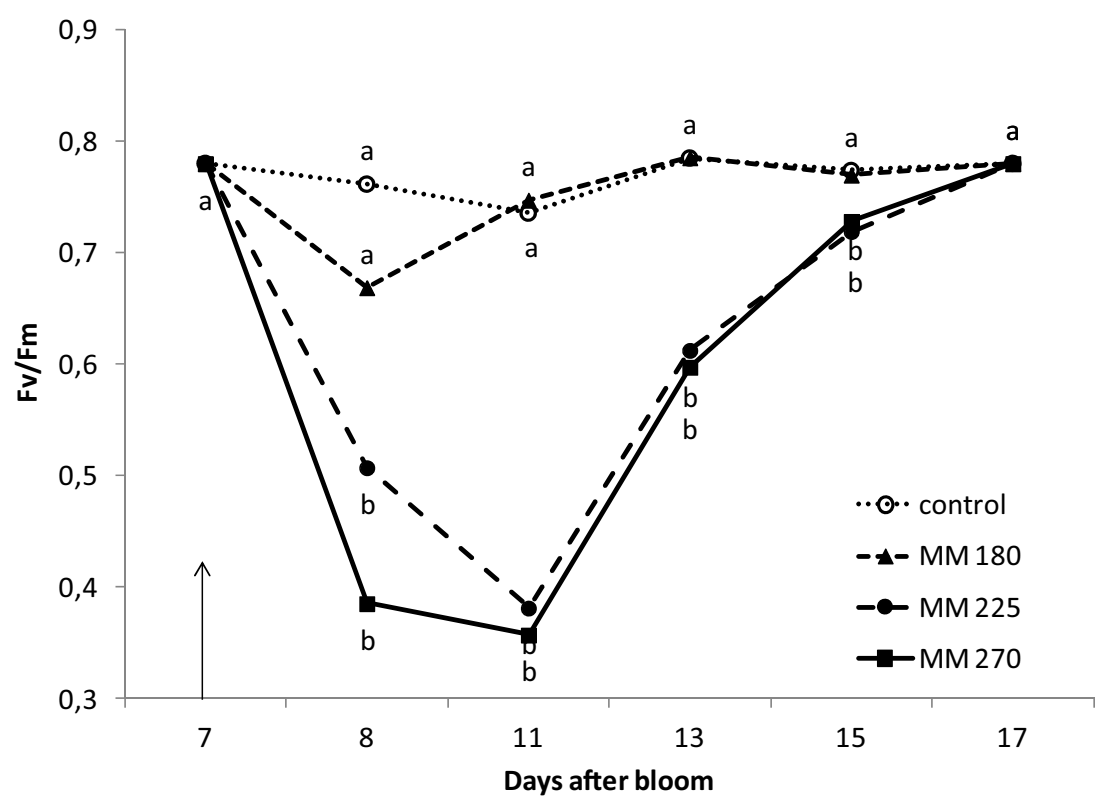

Figure 6. Effect of a single application of $0.1 \%, 0.125 \%$ or $0.15 \% \mathrm{v} / \mathrm{v}$ Brevis ${ }^{\circledR}\left[180,225\right.$ or $270 \mathrm{~g}$ Metamitron $(\mathrm{MM})$ ha $\left.{ }^{-1}\right]$ at full bloom $(\mathrm{FB})+$ 7 days (10 April 2014) on dark-adapted chlorophyll fluorescence (Fv/Fm) in leaves (Expt. 4). Treatments were applied using air-blast sprayer at $1,200 \mathrm{~L} \mathrm{ha}^{-1}$. Each data point is the mean of 4 trees x 5 leaves per treatment. Different letters for each day's measurements denote significant differences between the means according to DMRT at $P \leqslant 0.05$. Arrow indicates application date.

first application $(6 \mathrm{~mm})$ and $c a .150-200 \mathrm{~g} \mathrm{ha}^{-1}$ at the second $(10-12 \mathrm{~mm})$. Our findings showed optimal results with the lower concentration of $180 \mathrm{~g} \mathrm{MM} \mathrm{ha}^{-1}$ (figures 1-3) given in only one application ( $\mathrm{FB}+7=6$-mm stage). Even when yield was very high, and the MM concentration was slightly higher $\left(225 \mathrm{~g} \mathrm{ha}^{-1}\right)$ there was a good thinning effect with only one early application (FB+7; figure 5). Similar results of thinning that improves fruit-size distribution and saves working days on fruit hand-thinning were obtained with 'Gala', 'Red Delicious' and 'Pink Lady' in 2012 and 2013 in the same orchards (data not shown).

\subsection{The effect of temperature}

The reason for the strong response, even with the lower concentration of MM, could be the higher intensity of dark respiration in Israel at the critical time of fruitlet growth, which uses assimilates instead of converting them into new cell material in the fruit $[19,20]$. The average night temperature during April-May (from FB until FB+21) over the 3 years of the experiment $(2012,2013,2014)$ was $13.7^{\circ} \mathrm{C}, 12.8^{\circ} \mathrm{C}$ and $14.6^{\circ} \mathrm{C}$ respectively. These high night temperatures increase respiration $[19,21]$ and may increase the sensitivity of the fruitlets 
to photoassimilate deficiency [22-24]. As a result, the tree probably needs less MM compared to the "colder" orchards in Europe and the USA. The average night temperatures in applegrowing areas in Europe like Sud-Tirol in Italy or East-Malling in England are ca. $10{ }^{\circ} \mathrm{C}$ lower than in Israel during the three weeks after bloom [25].

Growing 'Empire' apples under controlled environmental temperatures, Yoon et al. [24] discovered the critical influence of high night temperatures on the consumption of assimilates, which increased fruitlet-abscission levels. The main finding was that high day/night temperatures $\left(29 / 21^{\circ} \mathrm{C}\right)$ in the first 3 weeks after bloom decrease net photosynthesis levels, causing significant abscission in comparison with low day/night temperatures $\left(24 / 13{ }^{\circ} \mathrm{C}\right)$, regardless of the different thinning treatments.

Another possible reason for the higher efficiency of MM in Israel is the higher average daily temperatures (3-year average of $28{ }^{\circ} \mathrm{C}$ in Israel vs. ca. $15{ }^{\circ} \mathrm{C}$ in Sud-Tirol), which can increase the efficiency of photosynthesis inhibition by MM compared to the lower temperatures in Europe. The average maximum day temperature during the first week after MM application in 2014 (Expt. 4) when photosynthesis was reduced (figure 6) was $28^{\circ} \mathrm{C}$. Together, these observations strengthen the hypothesis that temperature regime during the treatment has a dramatic influence on the efficiency of the chemical used for thinning [26]. The dramatic reduction in $\mathrm{Fv} / \mathrm{Fm}$ values in Israel (from 0.8 to 0.4 ; figure 6 ) and that reported in the USA by McArtney and Obermiller [12] (from 0.8 to 0.7 ) supports this hypothesis.

\subsection{Adapting to global warming}

Climate changes are likely to impact key aspects of temperate perennial horticultural physiology and production. For example recent observations of the timing of pome fruit flowering have shown a trend towards earlier emergence. In France and South Africa flowering of 'Golden Delicious' apple has advanced by ca. 3.0 and 2.0 days per decade respectively $[27,28]$. These changes have been associated with recently observed warming in these regions. With projection for warming to continue into the future [29] it is likely that the timing of flowering will continue to occur earlier and the risk for spring frost, or potential separation of the flowering periods of cross-pollinating species that could lead to poor fruit-set will increase. Darbyshire et al. [30] in Southern Australia and Luedeling et al. [31] demonstrated that flowering time may move in different directions in different locations under warming climatic conditions. For locations predicted to receive less winter chilling, a delay in achieving the chilling requirement may lead to an overall delay of flowering. However, those locations with stable or increasing chill will likely respond to climate change with earlier flowering.

The influence of global warming on aspects of plant physiology such as photosynthesis efficiency or respiration intensity, as we have shown in this study will be very significant in the future. These effects will be especially important in warm apple-growing areas such as East-Asia, Australia, Africa, Near-East and even parts of Europe and North America, and will need to adopt suitable techniques for maintaining productivity.

\section{Conclusion}

MM applied once at $180-225 \mathrm{~g} \mathrm{ha}^{-1}\left(150-190 \mathrm{mg} \mathrm{L}^{-1}\right.$ in the form of $0.100-0.125 \%$ Brevis $^{\circledR}$ at $1,200 \mathrm{~L} \mathrm{ha}^{-1}$ ) at the 6-mm fruit diameter stage resulted in significant fruit thinning which in turn caused a considerable shift to larger fruit size. These relative low effective doses noted in the warm apple growing area of Israel compared to the higher doses needed in Europe were likely due to the higher night temperatures for 3 weeks post application which increased respiration and caused assimilation deficiencies during that critical period of fruit development. This study, which showed that higher night temperatures can increase fruitlet sensitivity to the reduction of assimilates by MM, suggests that lowering the rate of MM used for chemical thinning could prove to be one way to adapt to global warming.

Acknowledgements. I am grateful to Maxi Shulman from Baraam for his valuable assistance with the experiments.

\section{References}

[1] Byers R., Flower and fruit thinning and vegetative:fruiting balance, in: Ferree D.C., Warrington I.J. (Eds.), Apples: Botany, production and uses, CABI Publishing, Wallingford, UK, 2003, pp. 409-436.

[2] Dennis F., The history of fruit thinning, Plant Growth Regul. 31 (2000) 1-16.

[3] Greene D., Costa G., Fruit thinning in pome- and stone-fruit: state of the art, Acta Hort. 998 (2013) 93-102.

[4] Moran R., Southwick S., Chemical bloom thinning of pome and stone fruits, In: Basra A. (Ed.), Plant growth regulation in agriculture and horticulture, The Haworth Press Inc., New York, NY, USA, 2000, pp. 223-254.

[5] Abeles F.B., Morgan P.W., Saltveit Jr. M.E., Ethylene in plant biology, Academic Press, New York, NY, USA, 1992, 414 p.

[6] Bangerth F., Abscission and thinning of young fruit and their regulation by plant hormones and bioregulators, Plant Growth Regul. 31 (2000) 43-59.

[7] Untiedt R., Blanke M., Effects of fruit thinning agents on apple tree canopy photosynthesis and dark respiration, Plant Growth Regul. 35 (2001) 1-9.

[8] Botton A., Eccher G., Forcato C., Ferrarini A., Begheldo M., Zermiani M., Moscatello S., Battistelli A., Velasco R., Ruperti B., Ramina A., Signaling pathways mediating the induction of apple fruitlet abscission, Plant Physiol. 155 (2011) 185-208.

[9] Eccher G., Botton A., Dimauro M., Boschetti A., Ruperti B., Ramina A., Early induction of apple fruitlet abscission is characterized by an increase of both isoprene emission and abscisic acid content, Plant Physiol. 161 (2013) 1952-1969.

[10] Basak A., Efficiency of fruitlet thinning in apple 'Gala Must' by use of metamitron and artificial shading, J. Fruit Ornam. Plant Res. 19 (2011) 51-62.

[11] Lafer G., Effects of chemical thinning with metamitron on fruit set, yield and fruit quality of 'Elstar', Acta Hort. 884 (2010) 531-536. 
[12] McArtney S.J., Obermiller J.D., Comparison of the effects of metamitron on chlorophyll fluorescence and fruit set in apple and peach, HortScience, 47 (2012) 509-514.

[13] Maxwell K., Johnson G.M., Chlorophyll fluorescence - a particular guide, J. Exp. Bot. 51 (2000) 659-668.

[14] Looney N.E., Growth regulator usage in apple and pear production, in: L.G. Nickell (Ed.), Plant growth regulating chemicals, CRC Press Inc., Boca Raton, FL, USA, 1993, pp. 1-26.

[15] Stern R.A., Ben-Arie R., Neria O., Flaishman M., CPPU and BA increase fruit size of 'Royal Gala' (Malus domestica) apple in a warm climate, J. Hort. Sci. Biotech. 78 (2003) 297-302.

[16] Stern R.A., Ben-Arie R., Applebaum S., Flaishman M., Cytokinins increase fruit size of 'Delicious' and 'Golden Delicious' (Malus domestica) apple in a warm climate, J. Hort. Sci. Biotech. 81 (2006) 51-56.

[17] Lakso A.N., Wünsche J.N., Palmer J.W., Corelli-Grappadelli L., Measurement and modeling of carbon balance of the apple tree, HortScience, 34 (1999) 1040-1047.

[18] Dash M., Johnson L.K., Malladi A., Severe shading reduces early fruit growth in apple by decreasing cell production and expansion, J. Amer. Soc. Hort. Sci 137 (2012) 275-282.

[19] Lakso A.N., Apple, in: Schaffer, B., Andersen P.C. (Eds.) Handbook of environmental physiology of fruit crops, Vol. 1, Temperate crops, CRC Press Inc., Boca Raton, FL, USA, 1994, pp. 3-42.

[20] Tromp J., Metabolic processes, in: Tromp J., Webster A.D., Wertheim S.J. (Eds.), Fundamental of temperate zone tree fruit production, Backhuys Publishers, Leiden, The Netherlands, 2005, pp. 39-54.

[21] Jackson J.E., Biology of apples and pears, Cambridge University Press, UK, 2003, 448 p.
[22] Lakso A.N., Early fruit growth and drop: The role of carbon balance in the apple tree, Acta Hort. 903 (2011) 733-742.

[23] McArtney S., White M., Latter I., Campbell J., Individual and combined effects of shading and thinning chemicals on abscission and dry-matter accumulation of 'Royal Gala' apple fruit, J. Hort. Sci. Biotech. 79 (2004) 441-448.

[24] Yoon T.M., Robinson T.L., Reginato G.H., Effects of temperature and light level on efficiency of chemical thinner on 'Empire' apple trees, Acta Hort. 903 (2011) 1085-1093.

[25] Palmer J.W., Prive J.P., Tustin S., Temperature, in: Ferree D.C., Warrington I.J. (Eds.), Apples: Botany, production and uses, CABI Publishing, Wallingford, UK, 2003, pp. 217-236.

[26] Robinson T.L., Lakso A.N., Predicting chemical thinner response with a carbohydrate model, Acta Hort. 903 (2001) 743-750.

[27] Grab S., Craparo A. Advanced of apple and pear tree full bloom dates in response to climate change in the southwestern Cape, South Africa: 1973-2009, Agr. For. Meteorol. 151 (2011) 406-413.

[28] Legave J., Farrera I., Almeras T., Calleja M., Selecting models of apple flowering time and understanding how global warming has had an impact on this trait, J. Hort. Sci. Biotech. 83 (2008) 76-84.

[29] IPCC. Summary for policymakers, in: Climate change 2013: The physical science basis, Cambridge University Press.

[30] Darbyshire R., Webb L., Goodwin I., Burlow E.W.R. Challenges in predicting climate change impact on pome fruit phenology, Int. J. Biometeorol. 58 (2014) 1119-1133.

[31] Luedeling E. Girvetz E.H., Semenov M.A., Brown P.H. Climate changes affects winter chill for temperate fruit and nut trees, Plos One 6 (2011) e20155. 